\title{
Culture and Interculturality in the Adult ESL Context in Urban Quebec: A Case Study
}

\author{
Nancy Dytynyshyn and Laura Collins
}

This article examines the treatment of culture and the development of interculturality in the transcripts of a complete 36-hour ESL course organized by a community center in Montreal. The adult participants came from a variety of linguistic and cultural backgrounds. The adult second-language class has been identified as a potentially rich context for the development of interculturality due to direct contact between students from diverse cultures (Magos E Simopoulos, 2009). However, addressing areas of cultural misunderstandings (discursive fault lines, Menard-Warwick, 2009) may be essential in the process. The research questions relate to the representation of Canadian culture, how the teacher views and approaches cultural issues, and any evidence that this approach promotes intercultural competence. Results show Canada represented as a culturally diverse community with French Canadian culture minimally represented. The teacher emphasized cultural adaptation and commonality of students' experience across cultures. She did not address discursive fault lines in whole-class contexts, but was able to capitalize on the contact between her multiethnic learners to facilitate intercultural communication and the development of relationships of trust with those normally seen as "other." There was insufficient evidence to conclude that her approach promoted interculturality, but we argue that it did provide key elements from which interculturality may develop.

Dans cet article, nous nous penchons sur le traitement de la culture et le développement de l'interculturalité dans les transcriptions découlant d'un cours complet d'ALS d'une durée de 36 heures et organisé par un centre communautaire à Montréal. Les antécédents linguistiques et culturels des participants adultes étaient variés. On avait identifié le cours d'ALS comme un contexte qui pourrait s'avérer fertile pour le développement de l'interculturalité en raison du contact direct entre les étudiants provenant de diverses cultures (Magos E Simopoulos, 2009). Toutefois, il pourrait être essentiel d'aborder des domaines d'incompréhension culturelle (failles discursives, Menard-Warwick, 2009) pendant le processus. La recherche porte sur la représentation de la culture canadienne, les opinions et l'approche des enseignants relatives aux enjeux culturels, et toute indication que cette approche promeut la compétence interculturelle. Les résultats démontrent un Canada représenté comme une communauté caractérisée par une diversité culturelle et dans lequel la culture canadienne française est à peine évoquée. L'enseignant a souligné l'adaptation culturelle et les points communs dans les expériences des étudiants de différentes cultures. Elle n'a pas traité de failles discursives devant toute la classe, mais a pu tirer profit du contact entre les ap- 
prenants multiethniques pour faciliter la communication interculturelle et le développement de relations de confiance avec ceux habituellement perçus comme "l'autre ». Alors qu'il n'y avait pas suffisamment d'indications que son approche promouvait l'interculturalité, nous affirmons que celle-ci offrait les éléments clés à partir desquels l'interculturalité peut se développer.

The population of Canada is a collection of people with roots in a multitude of cultural backgrounds. New Canadians are making their way not only to urban centers, but increasingly into suburban areas and regional centers. Canadians are traveling, studying, and working abroad as never before. What challenges do these meetings and mixings of culture present? Although many Canadians are becoming more culturally aware, simply learning about and acknowledging cultural differences is only the beginning. In this article, we use two terms that are used interchangeably in the literature (MenardWarwick, 2009), intercultural competence and interculturality, which include a "respect of difference, as well as the socioaffective capacity to see oneself though the eyes of others" (Kramsch, 2005, p. 553). Many would argue that interculturality is increasingly required for a peaceful, fully functional, multiethnic society.

The notion of culture itself has been understood in a variety of ways. It has often referred to products such as literature and the arts, to history and institutions, and to practices such as festivals and popular phenomena (Liddicoat, 2004). In this study, however, culture refers to "shared understandings and practices within groups of people" (Menard-Warwick, 2008, p. 622). This includes the above-mentioned products and practices, but more important, it also includes understandings or perspectives, that is, values and ways of seeing the world. Although these practices, perspectives, and products are shared, they also show a great deal of within-group differences, and are continually in the process of change. Whereas cultural awareness is achieved when individuals learn about and acknowledge differences, intercultural competence includes a respect of these differences and the "ability to transcend ethnocentrism, appreciate other cultures, and generate appropriate behavior in one or more different cultures" (Bennett, Bennett, \& Allen, 1999, p. 13). It describes a capacity to see cultural issues from multiple perspectives and to interact appropriately with those of other cultural backgrounds.

The foreign-language (FL) classroom has long been considered an ideal site for promoting awareness of the culture(s) associated with a target language. For the past decade, it has also been common to speak of teachers' and learners' development of interculturality through the FL curriculum (Knutson, 2006; Liddicoat, 2004; Sercu, 2006). However, it remains unclear whether actual practices in the FL classroom promote interculturality. A small number of case studies have examined FL teachers' approaches to teaching intercultural competence (Duff \& Uchida, 1997; Ryan, 1998). In a multina- 
tional survey of FL teacher opinion, Sercu concluded that although most of those in the FL teaching profession might value cultural awareness and intercultural competence, in reality these goals often take a back seat to linguistic objectives. In addition, many FL teachers feel ill prepared to tackle cultural issues.

In terms of promoting interculturality, teachers of multiethnic adult second-language (SL) classes may have an advantage over FL teachers. The Contact Hypothesis (Allport, 1954) maintains that interpersonal contact has the potential to change how individuals and groups think about and behave toward one another. The multiethnic SL class offers this contact as students from diverse backgrounds learn a lingua franca for use in their adoptive community. These classes thus "constitute highly supportive contexts for the development of intercultural competence" (Magos \& Simopoulos, 2009, p. 256). We know through anecdotal evidence, including our own teaching experiences, that students from widely varied ethnic, national, and religious backgrounds end up exchanging phone numbers, becoming friends, and sharing personal confidences (Dytynyshyn, 2008). Such developing relationships with those normally seen as other may be an indication of increasing intercultural competence. We now turn to the findings from the small body of research that has looked at interculturality in this context.

\section{Culture and Interculturality in the Multiethnic Adult Second-Language Context}

Some evidence indicates that SL teachers approach culture and interculturality differently from FL teachers. Menard-Warwick's (2008) double case study compared two teachers who both had vast "transnational experience" (p. 618), having lived long term (more than two decades) in both the United States and either Brazil or Chile. These teachers had culturally hybrid identities themselves and high levels of competence in the target language (English). One taught a multiethnic adult ESL class in California, and the other taught EFL in a Chilean university. One of the main findings was that the ESL teacher in California focused on cultural comparisons between the US and her multiethnic learners' countries of origin, whereas the EFL teacher in Chile focused on cultural change in Chile with her ethnically more homogeneous Chilean students. These findings demonstrate that the approach to teaching culture and interculturality may be influenced by the teaching context.

Further evidence of this in shown in Menard-Warwick's (2009) qualitative look at three university-level EFL classrooms in Chile and three community college ESL classrooms in California. Based on interviews with teachers as well as eight hours of observation in each class, Menard-Warwick examined how teaching culture is approached in these classes, how national cultures are portrayed, the process of co-construction of cultural representations by teachers and students, and the extent to which these teachers' pedagogies 
encouraged interculturality. In her findings, the talk in the California ESL classrooms (which like the context studied in this article, grouped adult learners from multiple ethnic backgrounds) was about the cultural adaptation of individuals as they adjusted to a new living context, cultural comparisons, including both similarities and differences, and cultural values as participants weighed in on the rightness or wrongness of particular cultural views. There was little talk of cultural change, which was frequent in the more homogeneous Chilean EFL classrooms. Again, this suggests that FL and SL teachers' approaches to cultural issues may vary.

Menard-Warwick (2009) added another dimension to the discussion of interculturality in the adult ESL context. She particularly focused on discursive fault lines (a term adapted from Kramsch's, 1993, discussion of "cultural faultlines"), which Menard-Warwick defined as "areas of cultural difference or misunderstanding that become manifest in classroom talk" (pp. 30-31). She believes that uncovering such fault lines is necessary for intercultural competence to develop, and she used classroom excerpts to illustrate the handling of discursive fault lines. In the ESL classes, these appeared over students' varied roles as parents or children, over the meaning of poverty in diverse cultures, and when the students' values with respect to immigration and education differed from those of certain political figures in the US. However, according to Menard-Warwick, the students often seemed more interested in convincing their classmates of the correctness of their point of view than listening to and understanding the other's perspective. In addition, the teachers' desire to cultivate a peaceful and collaborative atmosphere led them to "paper over differences before going on to the next activity" (p. 43). Menard-Warwick thus documented the handling of discursive fault lines in whole-class discussions, but these discussions "did not necessarily lead to interculturality" (p. 30).

Finally, the literature also indicates that although the multiethnic adult SL class seems to provide a natural contact that could potentially favor the development of interculturality, this advantage is not necessarily exploited by teachers. Magos and Simopoulos (2009) examined teachers of Greek as a second language in culturally diverse adult immigrant classes in Athens. They examined whether and to what extent the teachers "promoted effective intercultural communication while teaching the second language" (p. 255). The teachers they studied were all university graduates with diplomas in teaching Greek, and they were all relatively young (aged 28-38). The qualitative data came from semistructured interviews with 20 teachers and 22 students and through observations made in each of the classes.

The results of Magos and Simopoulos' (2009) study showed that only four of the teachers were able to take advantage of the experiences and backgrounds of their students. These four asked students about their past experiences and integrated their stories into the lesson plan. They supported the 
students personally and generally saw their learning difficulties as related to the challenging circumstances of their lives as immigrants. The other 16 saw the students' experiences only as a way to introduce a topic (e.g., Who has been to a museum?), with many regarding students' stories as unwelcome deviations in the lesson plan. They tended to remain aloof and uninvolved in the students' lives and attributed students' failure to learn to a deficient educational, cultural, or linguistic background. Students from cultures with perspectives closest to those of Greek culture were favored. Unable to "transcend ethnocentrism" (Bennett et al., 1999, p. 13), fully half of the teachers communicated in subtle, or not so subtle, ways that Greek culture was somehow superior to the home cultures of the students. The students felt this keenly and reacted by dropping out of the courses. In Magos and Simopoulos' view, most of the teachers were not interculturally competent themselves and were unable to take advantage of the natural contact between varying cultures in the classroom. They attribute this to inadequacies in teacher training.

To sum up, the teaching context may lead SL teachers to approach culture and interculturality somewhat differently than FL teachers, with a greater focus on cultural adaptation and cultural comparisons. Although the SL context has not received much research attention, the existing evidence suggests that SL teachers do not necessarily take advantage of the contact opportunities that multiethnic SL classes offer. Teachers may not have sufficient intercultural competence to be able to promote this aspect in their classes, and linguistic goals may simply take priority. They may also feel ill equipped for the task of addressing discursive fault lines when they arise. Even when intercultural issues are approached, there is probably a great deal of variety from one teacher to another and possibly from one country to another; clearly this is an aspect of SL teaching and learning that is in need of more research attention.

\section{The Current Study}

The current case study was undertaken to contribute to the body of literature exploring the teaching of culture and intercultural competence in multiethnic adult SL classrooms. We examine how one particular teacher attended to culture and how far pedagogical practices in her multiethnic adult ESL class in Montreal promoted the development of interculturality. Although bound by the limitations of any case study, such a glimpse into classroom practice may bring insight into pedagogical practices or uncover threads for future research.

The current study differs from earlier studies in three important ways. First, the target culture (C2) is more complex than most ESL or EFL contexts because Montreal is a multiethnic city in a French-language province in a bilingual nation. Unlike in most ESL contexts, the language that the students are learning is not the dominant language of the immediate community. Students are learning English in a city where the official language is French (al- 
though the dominant language spoken in fact depends on the neighborhood), in a province that is predominantly French-speaking, while becoming citizens of a nation that is predominantly English-speaking. Thus the representation of the $\mathrm{C} 2$ in this context could include reference to French, English, and other communities. Second, the teacher was unaware of the researchers' interest in culture and interculturality, which reduced the effect of researchers' expectations on the teacher's behavior. One of the teachers in Menard-Warwick's (2008) study felt that her attention to cultural issues during the eight hours of observation was not necessarily representative of her usual practices. Finally, other studies have observed only portions of a course, for example, eight hours per teacher in the case of Menard-Warwick $(2008,2009)$. Our study examines the transcripts from an entire 36-hour ESL course.

The research questions are:

1. How is Canadian culture (the $\mathrm{C} 2)^{1}$ represented in this ESL class?

2. How does this teacher view and teach culture?

3. Does this teacher's pedagogical approach encourage the development of interculturality?

\section{Method}

\section{Participants and Teaching Context}

The data used to address the three research questions were collected in 2003 in an advanced adult ESL course offered by a Montreal community center, part of a larger study conducted by the second author of this article.

The class met for two hours and 15 minutes (including a 15-minute break), two mornings a week for nine weeks from January to March, either at the community center or at a nearby university with which the center had a partnership. The class comprised 19 students, 13 female and 6 male, with ages ranging from one teenager to one man in his 60s; most of the students were in their 20s, 30s, or 40s and came from 12 countries with eight first languages (L1s). Only two nationalities were represented more than once: two Koreans and seven Iranians. A table listing the learners' country of origin, L1, age, and sex is provided in the Appendix. Some learners spoke other SLs, but information on these languages was not documented.

The teacher, Jill, was a 30-year-old L1 speaker of English with EFL teaching experience in Korea and Central Asia and ESL teaching experience in both English Canada and Quebec. She also spoke fluent French as a second language. Jill had grown up in English Canada, but had been living in Montreal for about five years at the time of the study. At the time, she was an MA student in applied linguistics at the university in question. The composition of the class and its format were typical of those offered by any number of community organizations in Montreal, although Jill probably had more formal TESL training and broader teaching experience than the average 
teacher in this context. Because the government-sponsored SL classes target French in Quebec, ESL courses for new Canadians in this context are often given by volunteer teachers who do not always have formal TESL training (Dytynyshyn, 2008).

All 36 class hours were video-recorded by a research assistant, herself an experienced ESL teacher. Whole-class discussions were transcribed, but pair and small-group interaction is not represented in these transcripts except when Jill was interacting with a small group and the interaction was audible. In the last half of the session, six students volunteered to wear lapel microphones, thus allowing us access to a subset of pair and small-group interactions. Data from five pairs working on a reading about adult children caring for aging parents (Collins, Dytynyshyn, \& Milsom, 2008) were also considered in this study, but no other pair or group-work interactions were included. Because the data had been collected a number of years before this study, we decided not to interview Jill about her perspectives on the teaching of culture and on pedagogical decisions made, as too much time had elapsed for this information to be considered reliable. However, we gave Jill the opportunity to comment on the data analyses and interpretation once they had been completed. These comments are included in the appropriate sections below.

The decision to make this particular class and teacher the focus of our case study was taken because we had both worked with the transcript data on the above-cited project and had noticed the same development of intercultural relationships among learners that we had observed in our own teaching and teacher-training experiences in other Montreal community ESL contexts. To summarize, this study is based on a qualitative examination of the 36 hours of class transcripts and on data from five pairs working for about 20 minutes on one activity. A description of the thematic analysis is outlined below.

\section{Data Analyses}

To address the first research question about the representation of the $C 2$, all references to Canadian culture were identified and examined. This included talk about Canadian, English Canadian, and French Canadian (including Quebecois) culture, as well as any mention of other cultural groups in Canada. The data were also examined to determine Jill's attitude toward the students' home cultures and languages relative to the C2 and the second language (L2).

To address the second research question about the teacher's primary approach to culture, the four categories outlined by Menard-Warwick (2009) and reproduced in Table 1 were adopted. Highlighting in various colors was used to identify instances of talk about culture so that their relative frequencies and length of instance would be more visually salient. References to both what Holliday (1999) considers large cultures (those associated with countries, languages, or ethnic groups) and small cultures (other 
Table 1

Teacher's Approach to Culture

(adapted from Menard-Warwick, 2009, p. 35)

\begin{tabular}{|c|c|}
\hline Approach & Definition \\
\hline Cultural Change & $\begin{array}{l}\text { Discussion of how today's practices, products, and perspectives } \\
\text { differ from those of the past }\end{array}$ \\
\hline Cultural Adaptation & $\begin{array}{l}\text { Discussion of the changes individuals experience as they adjust to } \\
\text { new contexts. }\end{array}$ \\
\hline Cultural Comparisons & $\begin{array}{l}\text { Discussion of the ways in which practices, perspectives, and } \\
\text { products of one group differ from or are similar to those of another }\end{array}$ \\
\hline Cultural Values & $\begin{array}{l}\text { Discussion of a particular group's beliefs about what is right and } \\
\text { wrong, valuable or worthless }\end{array}$ \\
\hline Cultural Information & $\begin{array}{l}\text { Description of a particular group's practices, products, or } \\
\text { perspectives without reference to adaptation, comparison, or values. }\end{array}$ \\
\hline
\end{tabular}

groupings that show cohesive behavior irrespective of national boundaries) were included. For example, a discussion about hippies was considered cultural as well as one about adult children caring for aging parents. Risager (2007) uses the term transnational to describe such cultural groupings, a term we retain. We also examined the transcripts to see how Jill represented her students' national cultures. Did she project a stereotypic view of Iranians or Iranian culture, for example? A homogeneous view of national cultures has been criticized (Kubota, 1999) as a means of maintaining unequal power relationships.

We also had to decide which classroom activities to code. Menard-Warwick (2008) chose to exclude most form-focused activities such as vocabulary exercises. This dataset, however, contained many references to culture as vocabulary was being discussed, so we decided to code reference to culture in all activities regardless of their pedagogical focus. As the coding proceeded, it became apparent that a good deal of talk about cultural representations was simply informational in nature. For example, the students read a piece about Canadian patterns of coffee consumption. A statement that $57 \%$ of Canadians drink coffee every day (Berish \& Thibaudeau, 1998) is definitely cultural, but does not fit neatly into cultural change, adaptation, comparison, or values (although any of these angles could be developed in the discourse). The discussion was oriented toward reading comprehension. Mentions of culture during vocabulary work also tended to be informational in nature, so a fifth coding category for cultural information was opened (see Table 1). To complete the observations of Jill's approach to culture, any sharing of personal experience or the elicitation of personal experience from the learners 
was noted. The extent to which the teacher drew on personal and learners' experience was pertinent in both Menard-Warwick (2008) and Magos and Simopoulos (2009).

The analysis to address the third research question was more challenging. Menard-Warwick $(2008,2009)$ did not code specifically for interculturality because identifying this in the data "requires particularly high levels of inference" (2008, p. 624). Following Menard-Warwick, we opted to look for evidence of learners becoming able to see cultural issues from multiple perspectives. This included learners reexamining their own cultural views or demonstrating curiosity about and acceptance of other views. As part of this analysis, we looked at how discursive fault lines and pedagogical practices were handled reflecting a contact theory approach.

\section{Results and Discussion}

We make a few brief observations of a general nature before examining each research question. Jill's focus was clearly on language skills, primarily speaking and listening, then reading, and lastly writing. Vocabulary was discussed more frequently than grammar, pronunciation, or pragmatics. The approach was communicative, with learners working in pairs or small groups for about $30 \%$ of the class time (Springer \& Collins, 2008). Although Jill did not speak of an intention to teach culture or interculturality, there was a great deal of reference to culture overall. Many references were brief, with little critical analysis by the speaker or listener. Tensions over cultural issues were rarely observed. Below we address the results as they pertain to each research question.

Research Question 1: How is Canadian Culture (the C2) Represented in this ESL Class?

The "heterogeneity of Montreal" (Knutson, 2006, p. 596) and Canada surfaced in the exchanges that took place in this class. One reading on food trends in Canada discussed the variety of ethnic foods that are now available from supermarkets in take-out format. One of the radio ads that Jill used for a listening activity was for a well-known Italian restaurant located within walking distance of the community center. The students themselves brought examples of their eating experiences in Montreal's Chinatown. Another student explained the Iranian New Year celebration and invited her classmates to attend the event. Montreal's St. Patrick's Day parade was discussed. These are relatively surface-level aspects of multiculturalism, topics that Sercu (2006) identified as being within the comfort zone of most teachers.

Somewhat surprisingly, however, few references were made to French Canadian practices, products, and perspectives. The entire 36 hours contained only 14 references to the cultural duality of the C2. Ten of these were references to the French language, with a learner or the teacher using his or 
her common knowledge of French as a resource for clarifying the meaning of an English word. Jill once specifically corrected the expression ${ }^{*} I^{\prime} m$ agree by pointing out the transfer from French that results in this error. The only representation of French Canadian culture came from one learner's complaint that she had been interviewed for a job requiring the applicant to make phone calls to a company's English-speaking customers, but because the interviewer had limited English skills, the interview had taken place in French. The student states, "You know that Quebecois ... doesn't have too much English.... It's true" (March 19). (The course began on January 15 and ended on March 30; we provide the dates to show that the examples span a range of classes across the term.) The teacher made no comment about the student's representation of French Canadians, but replied that conducting the interview in French was not fair because they were looking for an Anglophone.

Despite the absence of discussion about Quebecois culture, an understanding was evident among participants that the dominant language of Montreal was French, exemplified in Extract 1 below. $^{2}$ The relevant sections of the transcripts are in bold type.

Extract 1

$01 \mathrm{~T}$ : I am going to give you, for you to look at over the weekend, just some

02 information on... preparing for an interview. The the the types of things

03 that you /---/(hands out sheets) Cuz most of the time here, you'll have

04 an interview in in French, but you might also have an interview in English

05 so... it's nice to be prepared.

06 S: I passed an inter/---/ in English.

07 T: In English, oh, wow! Okay, good. So this is very relevant. (March 6)

A number of explanations are possible for the lack of reference to French Canadian culture. The Francophone/Anglophone divide in Canada may have been deliberately avoided due to its potential for opening discursive fault lines (we thank the reviewer who raised this issue). Certainly the teacher did not broach the subject. However, the above-mentioned job interview incident was also the only instance of student-initiated attention to this issue. The fact that there were no French Canadian learners in the group may partly explain why the subject did not seem to arise. Another explanation may be related to the teacher's goals. As noted above, her focus was on language; culture was dealt with as it arose in students' opinions or was presented in texts. Because most talk about culture of any length was text-related, and the classroom text Canadian Concepts 5 (Berish \& Thibaudeau, 1998) makes no specific mention of Francophone culture, its absence from the classroom talk is perhaps less surprising. ${ }^{3}$ Jill herself suggested that the lack of attention to Quebecois culture may have stemmed from the fact that several of the students had been living in Quebec for a number of years and were already familiar with many aspects of the culture. 
This is somewhat typical of the adult ESL context in Quebec. New arrivals generally acquire French first in order to be employable; many would already have attended government-sponsored French SL courses. Linguistic transfer from and reference to French in the data support Jill's view.

In contrast to many of the teachers in the Magos and Simopoulos (2009) study, there was no evidence of Jill portraying Canadian culture as superior to the learners' home cultures. Indeed, she highlighted some negative aspects of Canadian culture (such as a growing problem with credit-card fraud), did not react defensively when students made comments that were critical of the $\mathrm{C} 2$, and was respectful of their home cultures. For example, she indicated that she preferred to be addressed by her first name, but that students who were uncomfortable doing so could call her Miss Jill.

There is also evidence that Jill regarded the students' L1s as equal to the target language. Some of the teachers in Magos and Simopoulos (2009) believed Greek to be superior and that their students' difficulty in learning Greek stemmed "from the fact that they don't have basic structures in their mother-tongue, or they developed them in the wrong way ... so you have to get rid of them" (p. 260). In contrast, Jill attributes value to the learners' L1s by using them as a pedagogical tool in her linguistic focus. First, in pronunciation work, Jill grouped students by their L1s and had them translate an English dialogue into that language. They then had to practice the dialogue as if they were Anglophone tourists in their country, that is, in their mother tongue but with a strong English accent. This was to make them aware that they already had a good idea of what English sounded like; at the same time, the learners found it amusing. The learners then transferred this overall sound back to the original English dialogue. Second, in Extract 2 below, we see Jill drawing on the learners' L1s to bring out a transnational phenomenon: common tactics salespeople use when trying to make a sale in any culture.

Extract 2

01 T: What else could you say if you're selling? What do you say in your own language?

02 Try and translate it into English.

A number of turns later:

03 S1:We also use another Persian, another word in Persian.

04 /---/ I don't know. We say, occazion...occazion.

$05 \mathrm{~T}$ : occasion?

06 S2: /---/ French

07 S1:For example, I want to buy, to sell my home

08 T: uh-huh.

$09 \mathrm{~S} 1$ :and the price is very...reasonable and...the...house is very nice house. This is, this

10 is occazion.

$11 \mathrm{~T}$ : okay (writing)

12 S1:occasion

13 T: Okay, it's a once-in-a-lifetime deal, right? You'll never get another chance, ever 14 again, to buy...this product at this price...never, ever. 
15 S3: We say you are very lucky.

16 T: You're lucky.

17 S3:You are lucky /---/

18 T: Okay, it's your lucky day. It's your lucky day. (Feb. 26)

Finally, Jill does not set herself up as the expert on the C2. One student, N, had lived in Montreal for 10 years. Jill tells the class, "So if you need to know something about Montreal, $\mathrm{N}$ is the person to go to" (January 15). These examples indicate that Jill did not view the $\mathrm{C} 2$ or her own experience as superior to the learners', nor did she demonstrate a negative view of her students' L1s. In this respect, Jill is unlike most of the teachers in the Magos and Simopoulos (2009) study, whom the authors identified as lacking intercultural competence.

\section{Research Question 2: How Does This Teacher View and Teach Culture?}

To establish which of the five coding categories (Menard-Warwick's four plus our cultural information category) best captured Jill's focus, we considered primarily the length and depth of the discussions rather than their frequency. The cultural references in form-focused activities (such as discussions of vocabulary) were generally short segments compared with those arising in meaning-focused work. Lengthier culture-related sections included discussion of reading and listening texts that presented Canadian cultural issues (coffee consumption, fast-food trends, credit-card theft, Valentine's Day shopping, advertising). In the only lengthy writing activity, the students worked in groups over several class periods to co-author a booklet destined for distribution through the community center to newcomers to Canada like themselves. In it they gave their advice on issues such as housing, climate, health services, and schooling in Montreal.

Overall, in terms of the five categories, Jill's dominant approach was one of cultural information and cultural adaptation. Cultural change also surfaced through a transnational look at the culture of beauty over the ages and the Canadian food trends text. Cultural comparisons tended to be multiple, shorter interactions, and there was little in the way of discussion of cultural values. However, Jill generally handled discussion of opinion in a small-group format rather than as a whole-class activity, so much discussion of cultural values would not have been recorded. For example, following the listening text on beauty over the ages, the learners discussed value-based questions in pairs. One question had them rank wealth, intelligence, physical appearance, character, and personality from most to least important. In fact, Jill confirmed that many students engaged in values-based discussions in small groups. However, although the whole-class wrap-up appears in the transcript, the pair discussions do not. This pattern was repeated many times throughout the data, leading to a possible skewing of the assessment of the dominant categories toward information and adaptation and away from cultural values. 
Another way of looking at the teacher's general approach relates to national versus transnational concepts of culture (Risager, 2007). Kubota (1999) is critical of promoting a homogeneous view of national cultures, claiming that this usually serves to maintain unequal power relationships. Jill did elicit students' contributions about your countries, as Menard-Warwick (2008) documents in her multiethnic ESL teacher's case, but did so comparatively infrequently. In the first eight hours of the course (a period consistent with Menard-Warwick), the teacher used the concept of your country only twice. Both instances came in one pre-activity introducing the text on the growth of pre-prepared meals in Canada, as Jill sought cultural comparisons about the length of time people spent preparing food. Jill seems to have focused less on the learners' national cultures and related comparisons than did the ESL teacher in Menard-Warwick. Like Menard-Warwick, however, we found little evidence of the essentializing of differences between nations that Kubota writes about. Opinions were solicited and treated as personal opinions, not as representations of a particular nation or language group. Jill suggests that this may be partly explained by the presence of seven Iranians in the class, who were very much individuals, displaying great variety both in terms of outward cultural expressions such as dress and in terms of personality and manner of social interaction. We identified only one occasion when a comment of Jill's could be construed as essentializing differences. As she introduced the reading on credit-card fraud, she asked the learners to list items one might find in a purse or handbag. After listing perhaps 25 items, one student proposed a gun. Jill replied, "Gun? Maybe if you're in the US" (February 5).

Rather than seeing the learners as representatives of their home countries, Jill tended rather to treat them as individuals and to draw out their shared experiences. The learners were members of a small (Holliday, 1999) but transnational (Risager, 2007) cultural group: new arrivals in Montreal. Jill viewed the learners as being in a position to give expert advice to other newcomers through the booklet project. The fact that shared perspectives existed in this cultural group was humorously illustrated in Extract 3 when Jill asked the class about the meaning of the expression eyes wide as a toddler's in the aging-parent text the students were discussing.

Extract 3

01 T: "She looked at me eyes wide as a toddler's." What's a toddler?

02 S1:Toddler is a baby, a baby, it's one euh two years.

03 T: Yeah, a a child one or two years old. Toddler.

04 S2:----/

05 T: Yeah, he's just started to walk, yeah, yeah.

06 S3: Like newcomer to Canada (laughter).

07 T: Like, like a newcomer to Canada. (March 19)

TESL CANADA JOURNAL/REVUE TESL DU CANADA 
In other discussions, the learners became members of more transnational groups; they were "adult-children-caring-for-aging-parents," buyers and sellers, judges, and witnesses of crime. In each case, the emphasis was on the commonalities of their experiences rather than national cultural differences. It was in fact one of Jill's goals for the course that the learners would get along as a group, and focusing on commonalities rather than differences was one means to this end. This is not to conclude that underneath we are all the same, but rather that there is common ground no matter how different we may seem. To sum up, like the SL teachers in Menard-Warwick (2008, 2009), Jill emphasized cultural adaptation over cultural change. However, due to Jill's more transnational approach, she did not develop cultural comparisons as much as Menard-Warwick's SL teachers.

Like the ESL teacher in Menard-Warwick's (2008) study and the interculturally competent minority of teachers in Magos and Simopoulos (2009), Jill drew heavily on the learners' experiences. However, she was more measured in sharing her own experience and quite reserved in giving her opinion. When she drew on her own experience, it was usually briefly and often to illustrate the meaning of a word or expression. Occasionally, she used her own experience to make cultural comparisons and talk about cultural adaptation. In Extract 4, Jill is circulating while the students work on the newcomers' booklet. She interacts with the students who are writing about transportation, who have included advice about bus line-up etiquette in Montreal. Jill affirms their decision to include this information by sharing a personal cross-cultural experience, and in so doing also identifies with them as having to adapt to new cultural norms.

Extract 4

$01 \mathrm{~T}$ : That's good information. /---/ something that people /---/.

02 Do people wait in line in Mexico for the bus? Yeah. In China, in China it's like a

03 fight. ... In China, really, because there are so many people. I was in China once

04 and people are pushing each other to get on the bus. Very shocking for a Canadian.

05 And at the end, I was pushing as well. I took a seat from an old lady (March 5)

In summary, Jill tended to focus primarily on language; however, when discussing culture, information about Canadian culture and cultural adaptation to life in Canada were the most prominent categories in the whole-class talk. She drew on information from the learners' home cultures and her own stories sparingly, but drew heavily on their personal experience and opinions as individuals.

Research Question 3: Does This Teacher's Pedagogy Encourage Interculturality?

To begin, we examined the transcripts to identify the teachers' pedagogical approach with respect to interculturality. We did not see the pedagogy advocated by Menard-Warwick (2009), that of using discursive fault lines (areas 
of difference or misunderstanding) as springboards for helping learners to examine their own cultural views and interact with those expressed by others. Although potential discursive fault lines (especially areas of difference) arose frequently, Jill did not explore them. For example in Extract 5, the class has been focusing on the use of still, anymore, and used to. They made a series of statements about themselves, some true, some untrue. In small groups they had been trying to avoid lie-detection and fool their questioning classmates. In the whole-class wrap-up, this interesting exchange on hippies arose. Although it was a natural opener for examining cultural change and the varying cultural values that led some societies but not others to experience the hippy movement (a potential discursive fault line), the teacher kept the discussion to a minimum and quickly returned to the task goal (line 14).

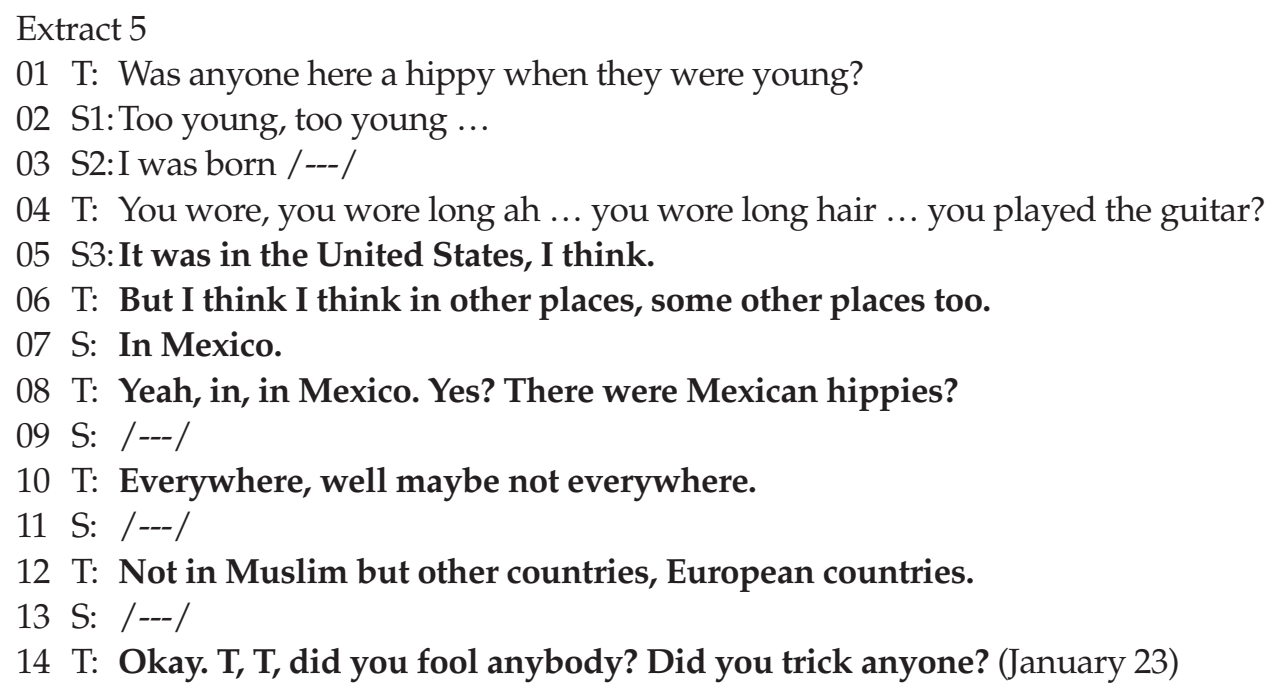

In the few instances when tension over cultural issues emerged in the classroom talk, Jill acknowledged the learners' views, but redirected the Ss to the language task. A notable example arose during the preparation for the newcomers' booklet. Working in groups, the students were to prepare a list of things they wish they had known (which was also the language focus of that particular task) about Canada before they arrived. In the teacher-fronted wrap-up, the groups reported to the class. A group of three men dominated many turns as the discussion opened. They wished they had known about all the bureaucracy in Canada, how money was god, how little hospitality there was, how long hospital wait times were, and how artificial relationships were. Jill calmly listed these issues on the board, questioning only to clarify their point, but not reacting to or passing any judgment on their views. Jill still recalls what was going through her mind during this incident. She knew these men were deeply unhappy with their situation in Canada and that their comments were a means of expressing this. Any suggestion that their criticisms might not be entirely true would communicate a judgment that their situation was not really so bad and 
that their feelings of unhappiness were not valid. So Jill chose not to comment on their list of grievances (for examples of intercultural competence assessments, see Deardorff, 2011; Sercu, (2004; Sinicrope, Norris, \& Watanabe, 2007).

When they next listed the closed mentality in Canada, the research assistant, who had also developed a relationship with the learners by this point, interjected, "Don't you guys like it here at all?" (February 12). Jill diffused the tension by saying that a lot of interesting things were coming up and asked if anyone had any practical advice, which diverted attention from the emerging fault line and directed Ss back to the task. Jill also had a tendency to defer "big questions" by saying that they could talk about these issues more during the break.

Jill's practice of deferral could reflect her concern to keep abreast of the language-learning goals or unwillingness to explore issues further. In either case, discursive fault lines were not explored as recommended by Menard-Warwick (2009), and potential opportunities for developing intercultural competence were thus lost. Jill's response to this finding was that she was indeed aware of intentionally preempting the appearance of discursive fault lines during whole-class discussion. She preferred not to risk potentially abrasive comments from two students in particular, based on her observations of their interventions in informal exchanges with their classmates. When students express themselves on controversial issues in a whole-class context, there is a risk that one or two highly opinionated students may dominate the discussion and that more introverted learners may not participate. The positive affective climate of the class can be compromised. In this nonacademic learning context, when students are not comfortable in the class, they drop out (Magos \& Simopoulos, 2009). Deferring such discussions to break time or small-group discussion allowed Jill to maintain a harmonious whole-class atmosphere, which was one of her objectives. Thus the decision not to address discursive fault lines was influenced by the particular students and the teacher's goals for the class.

Furthermore, in a communicative, student-centered classroom, the decision is not simply whether to pursue discursive fault lines, but also whether to do so in the whole-class or pair/small-group context. Doing so in small groups may reduce the risk of an unpleasant classroom environment. However, the teacher loses a good deal of control over the outcome. The Chilean EFL teacher in Menard-Warwick (2008) sees educators as agents of social change. From this perspective, a teacher may actually bring a certain agenda of his or her own to discursive fault lines that arise and may not be able to lead the discussion to the hoped-for conclusion if left to pair or small-group contexts. Our data cannot speak to this issue because we had no instances of discursive fault lines in the one paired activity that we examined.

Although Jill did not promote intercultural competence by addressing discursive fault lines in a whole-class context as envisaged by Menard-Warwick (2009), she actively promoted direct contact between learners. Ryan 
(1998) states that one way to acquire intercultural competence is through "direct and indirect personal contact" (p. 151). She maintains that "actively engaging" (p. 151) with people who have diverse cultural identities, values, and behaviors can help develop such competence. Jill was intentional about having students interact. The classroom was arranged in five groups of four desks pushed together, but Jill ensured that the students mingled rather than staying in comfortable pairs and groups. In most lessons, at least one activity could not be completed without everyone getting up, moving around, and interacting with numerous classmates. Jill grouped students for tasks by having them line up in order of their birthdate, height, or length of residence and forming groups from these lines. Often she paired and grouped students herself, making them change seats to form new groups. It seems that not all students liked this, but Jill made her purpose clear:

We're going to continue to change the groups. Some people said they didn't want to change the groups, but ... the reason we change the groups is so that you get a chance to speak to other people ... ah ... so that um ... you're not just sitting in the same place all the time, you get to meet other people, you get to talk to other people, so we're going to continue with the groups. (February 21)

By insisting that learners interact with all their classmates, Jill facilitated intercultural communication. Although the primary focus of the pair and group tasks was linguistic, some also included a cultural component, particularly those based on the reading and listening texts, as well as the redaction of the newcomers' booklet. Other tasks had students give opinions and come to consensus on values-based questions (such as finding a suitable sentence for a crime) in culturally mixed groups. If Jill had not mixed the students in this way, they would have tended to interact only with the few classmates sitting close by, who in many cases would be those who shared their L1.

Jill's ability to get the students to mix stands in contrast to that of the teacher reported on in an ethnographic study carried out in a high school social studies classes in urban British Columbia (Duff, 2002). Sixty percent of the learners in this class were non-native speakers of English from various Asian countries. Forty percent were L1 English-speakers, half of them with Asian or First Nation heritage. Despite the teacher's desire to foster respect for cultural identity in order not to marginalize the non-native speakers, the discourse analysis did not reveal much success in the development of interculturality. Duff's teacher had a culturally mixed class, but the students did not know one another even at the half-way mark of the school year. They sat in fixed, culturally homogeneous groupings, and those in the back could hardly hear the contributions of those in the front. The teacher presented issues that held good potential for building intercultural competence, but the students had had so little direct contact that there was no relationship or trust 
on which to build the necessary sharing of views. Her attempts to get students to voice their opinions were largely unsuccessful. This context and ours differ in many ways-not the least of which is the age of the students-but it may be that teachers need to take a more proactive approach to having students interact with and get to know one another to build a community where students feel more comfortable expressing their views and listening to those of others.

Jill's pedagogical approach, therefore, facilitated contact between learners in small groups rather than addressing discursive fault lines in whole-class activities. However, both pedagogies are simply means of fostering intercultural communication. In and of themselves they are not evidence of interculturality, although they may promote it. Menard-Warwick (2009) found almost no evidence for developing interculturality among the students she observed; that is, there was no evidence of the learners' growing ability to see themselves and their culture through the eyes of another (Kramsch, 2005). Nor was any observed in our study. Because much of the opinion and values-based discussion took place in pairs or small groups, observation of the interaction in these contexts might have yielded such data; it may also be, however, that evidence of the development of interculturality needs to be probed through measures designed to elicit behavior and attitudes that would demonstrate intercultural competence (Deardorff, 2011; Sercu, 2004; Sinicrope et al., 2007).

It is clear, however, that Jill's approach went beyond encouraging intercultural communication to encouraging intercultural relationships. She expressed many times that the purpose of a particular activity was for the students to get to know one another. She asked them to survey one another about interesting past experiences. On another occasion, students were grouped according to their position in the family (eldest, middle child, and youngest) and discussed the advantages and drawbacks of their (shared) positions. On three occasions, she had all the students draw pictures on the board to represent their thoughts or feelings. Each then interpreted his or her picture to a partner. In every class students were contributing personal experiences and expressing opinions in small groups. A number of times Jill opened the post-activity wrap-up by commenting on how interesting their conversations had been. That she promoted relationships was demonstrated in the last activity of the class where she said:

Everyone's been working a lot together in the class in different groups, in different pairs, and um ... I've seen a lot of people, well, everyone, everyone has helped each other, I think. And uh, a nice way to end the class is to thank people for how they have helped you or for, for bringing something to the class that you enjoyed. Okay? So for example, I might thank J, for always smiling. 'Cuz she's 
always smiling, and it's very nice to see, you know. Or I might thank $Z$ for, for showing ... ah, courtesy, old-fashioned courtesy, and always calling me madame (laughter). (March 20)

The students and teacher then circulated and thanked one another.

Forming relationships of trust with those normally seen as other is not part of the definition of interculturality used in this article. However, openness to people of other cultures and the ability to suspend judgment have been consistently identified as attitudes that are part of the complex construct of intercultural competence (Byram, 1997; Deardorff, 2006, 2011; Sercu, 2004). We argue that developing intercultural relationships of trust may represent acts of looking beyond otherness or of transcending ethnocentrism. Intercultural friendships are not equivalent to intercultural competence, but they reflect attitudes that are aspects of it.

Was there evidence of intercultural relationships of trust in Jill's class? In the 12th of the 18 classes (February 27), a have you ever activity in which Ss probed one another's unusual past experiences led to the students talking about their experiences, including seeing missiles and facing impending death. This level of disclosure continued in the next class (March 5) as two students reported in some detail on painful job experiences in their home countries. One had to leave the course before it was over, so Jill had the class learn a song to say goodbye (February 26). The departing student was moved to tears. A few classes later, one learner reported that she had cried when she read the agingparent story (March 19). In the wrap-up to this activity, the teacher abandoned her linguistic objectives as several students shared personal experiences and worries about their aging or geographically distant parents. Having access to the entire 36-hour course (as opposed to an 8-hour segment) allowed for observation of this developing closeness and trust over time.

Evidence of developing intercultural relationships of trust also came from the inside look at five pair interactions recorded as students worked on the aging-parent story. This was the only paired interaction of the dataset examined for this study. In one pair, after finishing the task questions, the women discussed their job situations and exchanged phone numbers. In a second, an Iranian and a Korean discussed their jobs before coming to Canada, the value of stay-at-home mothering, and cultural representations from their home cities. In a third, an Eastern European man noticed his Mexican partner's silence and said, "What are you thinking about?" (March 19). He then listened as his partner shared some immigration problems. The empathy demonstrated in these pair interactions is also one of the attitudinal components of intercultural competence in Deardorff's $(2006,2011)$ model. These examples came from pair interaction for only one 25-minute activity.

In summary, with respect to research question 3, we cannot conclude that Jill's approach of promoting contact, intercultural communication, and in- 
tercultural relationships encouraged interculturality according to the definition used here. On the other hand, neither was Menard-Warwick (2009) able to substantiate interculturality using an examination of discursive fault lines. However, unlike most of the teachers in Magos and Simopoulos (2009) and the teacher in Duff (2002), Jill was able to foster intercultural communication and cross-cultural relationships of trust through direct contact while maintaining a supportive classroom environment.

\section{Conclusion}

The answers to the three research questions that guided this study can be summarized as follows. The French-English dual nature of the target culture was not a focus of the teacher's or the students' attention. The teacher focused on language, yet brought cultural issues to the classroom through reading and listening texts and through a writing project. Culture-related exchanges were brief during form-focused work, whereas meaning-focused tasks led to lengthier considerations of cultural issues. Overall, in the whole-class time, issues of cultural adaptation and cultural information about Canada were the most prominent. The teacher drew heavily on the students' experience and opinion, generally approaching culture from a transnational perspective. There is evidence that her approach of promoting direct contact between her ethnically heterogeneous students fostered intercultural communication and relationships of trust with those normally seen as other, although there was no evidence of interculturality.

This study is subject to a number of limitations. First, as with most of the published research in this area, the data were coded by only one researcher without establishing interrater reliability. Given the subjective nature of the data, at times a given comment could have been placed in more than one category. However, two features mitigated this limitation. The goal of the study was to identify broad tendencies, not detailed lists. In addition, conclusions were based on the length and depth of cultural discussions and not counts of actual frequency. Second, this is not an ethnographic study, but is based on recorded observational data of which the researchers were not eyewitnesses. Because the original data were collected in 2003, there could be no triangulation with teachers' or students' interviews, although the teacher did have the opportunity to comment on the analyses. Of course, the advantage is that this study represents a look at what really happens in a multiethnic adult ESL class and not what the teacher or students want a researcher to think happens in their class. Furthermore, having access to data for the entire 36-hour class allowed trends to come to light that might have remained obscure in only eight hours of selective observation.

A third limitation, as mentioned above, is that a great deal of significant exchange on cultural issues and values might have taken place in the context

of pair and group work, at break time, and in other informal contexts that 
were not captured in this dataset. With the evidence presented that these might have been particularly rich exchanges in terms of culture and interculturality, this represents an avenue worth pursuing in further research.

Despite these limitations, we believe that the findings have encouraging implications for second-language teaching, particularly in multiethnic classes. Foreign-language teachers must devote time and energy to fostering contact between their learners, the C2, and speakers of the L2. North American universities struggle to find ways to encourage foreign and local students to interact. In the multiethnic SL class, however, contact is inherent. Although developing the skills to manage whole-class discussion of culturally sensitive topics may seem overwhelming and possibly threatening to novice teachers, adopting some of the techniques that Jill used to promote contact would not. For example, Jill grouped students by numbering them off by length of residence, by birth order, and by common interest. Intentionally grouping students so that they have significant contact with all their classmates can foster relationships from which interculturality may grow ${ }^{4}$ (see Bryam, Gribvoka, \& Starkey, 2002, for additional suggestions for promoting intercultural skills and knowledge among L2 learners). This is not to suggest that tensions over cultural differences are to be avoided, or that addressing discursive fault lines critically is not a productive means of developing interculturality (as argued by Menard-Warwick, 2009). However, we wonder whether it is possible effectively to address discursive fault lines in SL classes if students have not first developed relationships of trust. This would seem to be an important question for future research. Another issue that merits exploring is whether discursive fault lines are best addressed in a teacher-controlled whole-class format or in small groups. The answers to these questions would provide teachers and teacher trainers with much needed guidance for dealing constructively with discursive fault lines. It will also be important to determine appropriate ways to document the development of interculturality among students who experience teaching approaches designed to foster its growth.

\begin{tabular}{|c|c|c|c|}
\hline \multicolumn{4}{|c|}{ Transcription Conventions } \\
\hline |---/ & unintelligible speech & S: & an unidentified student \\
\hline |---.../ & an unintelligible section & $\mathrm{T}:$ & the teacher \\
\hline$\% \%$ & simultaneous speech & Ss: & a group of students/the whole class \\
\hline$\ldots$ & pause & & the research assistant \\
\hline-- & interrupted speech & italics & Transcribers' comments \\
\hline
\end{tabular}


${ }^{3}$ One of the reviewers wondered why a text that did not address this issue would be chosen for an adult ESL class in Montreal. When the class took place (2003), we were not aware of any Canadian-made materials that did. Canadian Concepts (1998) was relatively recent and provided both reading and listening texts about life in Canada that Jill believed would be of interest to this group of learners.

${ }^{4}$ We thank the reviewer who directed our attention to this resource.

\section{Acknowledgments}

We thank Teresa Hernández González, Sara Kennedy, Susan Parks, and three anonymous reviewers for their valuable feedback on earlier versions of this article. Funding for this project was provided through two research grants awarded to the second author: a standard research grant from the Social Sciences and Humanities Research Council of Canada, and a team grant from the Quebec Ministry of Education (Fonds Québecois de la recherche sur la société et la culture).

\section{The Authors}

Nancy Dytynyshyn is an adult-ESL teacher in Saguenay, Quebec. She is pursuing a master's in applied linguistics at Concordia University, Montreal. Her interests include second-language teaching in the multiethnic classroom, pair and group work dynamics, and teaching pronunciation.

Laura Collins is an associate professor of applied linguistics in the Department of Education at Concordia University and co-editor of the Canadian Modern Language Review. Her research interests include the relationship between teaching practices and language-learning outcomes and the promotion of cross-curricular and cross-linguistic collaboration in second-language education.

\section{References}

Allport, G.W. (1954). The nature of prejudice. Cambridge, MA: Addison-Wesley.

Bennett, J.M., Bennett, M.J., \& Allen, W. (1999). Developing intercultural competence in the language classroom. In R.M. Paige, D.L. Lange, \& Y.A. Yershorva (Eds.), Culture as the core: Integrating culture into the language curriculum (pp. 13-46). Minneapolis, MN: CARLA, University of Minnesota.

Berish, L., \& Thibaudeau, S. (1998). Canadian Concepts 5. Scarborough, ON: Prentice-Hall Canada.

Byram, M. (1997). The intercultural dimension in "language learning for European citizenship." In M. Byram \& G. Zarate (Eds.), The sociocultural and intercultural dimension of language learning and teaching (pp. 17-20). Strasbourg, France: Council of Europe.

Byram, M., Gribvoka, B., \& Starkey, H. (2002). Developing the intercultural dimension in language teaching: A practical introduction for teachers. Strasbourg, France: Council of Europe.

Collins, L., Dytynyshyn, N., \& Milsom, C. (2008, November). Grammar in pair work: The inside story. Paper presented at the annual Société pour la promotion de l'enseignement de l'anglais, langue seconde, au Québec (SPEAQ) convention, Quebec.

Deardorff, D.K. (2006). Identification and assessment of intercultural competence as a student outcome of internationalization. Journal of Studies in International Education, 10, 241-266.

Deardorff, D.K. (2011). Assessing intercultural competence. New Directions for Institutional Research, 149, 65-79.

Duff, P.A. (2002). The discursive co-construction of knowledge, identity, and difference: An ethnography of communication in the high school mainstream. Applied Linguistics, 23, 289-322.

Duff, P.A., \& Uchida, Y. (1997). The negotiation of teachers' sociocultural identities and practices in postsecondary EFL classrooms. TESOL Quarterly, 31, 451-486. 
Dytynyshyn, N. (2008). Launching a community-based ESL program. Concordia Working Papers in Applied Linguistics, 1, 55-75.

Holliday, A. (1999). Small cultures. Applied Linguistics, 20, 237-264.

Knutson, E. (2006). Cross-cultural awareness for second/foreign language learners. Canadian Modern Language Review, 62, 591-610.

Kramsch, C. (1993). Context and culture in language teaching. Oxford, UK: Oxford University Press.

Kramsch, C. (2005). Post 9/11: Foreign languages between knowledge and power. Applied Linguistics, 26, 545-567.

Kubota, R. (1999). Japanese culture constructed by discourses: Implications for applied linguistics research and ELT. TESOL Quarterly, 33, 9-35.

Liddicoat, A.J. (2004). Intercultural language teaching: Principles for practice. New Zealand Language Teacher, 30, 17-23.

Magos, K., \& Simopoulos, G. (2009). “Do you know Naomi?": Researching the intercultural competence of teachers who teach Greek as a second language in immigrant classes. Intercultural Education, 20, 255-265.

Menard-Warwick, J. (2008). The cultural and intercultural identities of transnational English teachers: Two case studies from the Americas. TESOL Quarterly, 42, 617-640.

Menard-Warwick, J. (2009). Co-constructing representations of culture in ESL and EFL classrooms: Discursive faultlines in Chile and California. Modern Language Journal, 93, 3045.

Risager, K. (2007). Language and culture pedagogy: From a national to a transnational paradigm. Clevedon, UK: Multilingual Matters.

Ryan, P.M. (1998). Cultural knowledge and foreign language teachers: A case study of a native speaker of English and a native speaker of Spanish. Language, Culture and Curriculum, 11(2), 135-153.

Sercu, L. (2004). Assessing intercultural competence: A framework for systematic test development in foreign language education and beyond. Intercultural Education, 15, 73-89.

Sercu, L. (2006). The foreign language and intercultural competence teacher: The acquisition of a new professional identity. Intercultural Education, 17, 55-72.

Sinicrope, C., Norris, J., \& Watanabe, Y. (2007). Understanding and assessing intercultural competence: A summary of theory, research, and practice (technical report for the foreign language program evaluation project). Second Language Studies, 26, 1-58.

Springer, S., \& Collins, L. (2008). Interacting inside and outside of the language classroom. Language Teaching Research, 12(1), 39-60. 


\begin{tabular}{|c|c|c|c|c|}
\hline \multicolumn{5}{|c|}{$\begin{array}{c}\text { Appendix } \\
\text { Learners' L1, Country of Origin, Age, and Sex } \\
\text { (grouped by first languages in alphabetical order) }\end{array}$} \\
\hline & $\angle 1$ & Country of origin & Age & Sex \\
\hline 1 & Arabic & Lebanon & $20 \mathrm{~s}$ & $\mathrm{~F}$ \\
\hline 2 & Farsi & Iran & $20 \mathrm{~s}$ & $\mathrm{~F}$ \\
\hline 3 & Farsi & Iran & $20 \mathrm{~s}$ & $\mathrm{~F}$ \\
\hline 4 & Farsi & Iran & $30 \mathrm{~s}$ & $\mathrm{~F}$ \\
\hline 5 & Farsi, Khansari & Iran & $40 \mathrm{~s}$ & $\mathrm{~F}$ \\
\hline 6 & Farsi & Iran & $40 \mathrm{~s}$ & M \\
\hline 7 & Farsi & Iran & $50 \mathrm{~s}$ & $\mathrm{~F}$ \\
\hline 8 & Farsi & Iran & $60 s$ & M \\
\hline 9 & French & France & $40 \mathrm{~s}$ & M \\
\hline 10 & Korean & Korea & $30 \mathrm{~s}$ & $\mathrm{~F}$ \\
\hline 11 & Korean & Korea & $30 \mathrm{~s}$ & $\mathrm{~F}$ \\
\hline 12 & Polish & Poland & $50 \mathrm{~s}$ & $\mathrm{~F}$ \\
\hline 13 & Romanian & Romania & $50 \mathrm{~s}$ & $\mathrm{~F}$ \\
\hline 14 & Russian & Kazakhstan & $30 \mathrm{~s}$ & $\mathrm{~F}$ \\
\hline 15 & Russian & Moldova & $40 \mathrm{~s}$ & $M$ \\
\hline 16 & Russian & Ukraine & $40 \mathrm{~s}$ & M \\
\hline 17 & Spanish & Argentina & $20 \mathrm{~s}$ & $\mathrm{~F}$ \\
\hline 18 & Spanish & Chile & teens & $\mathrm{F}$ \\
\hline 19 & Spanish & Mexico & $20 \mathrm{~s}$ & $\mathrm{M}$ \\
\hline
\end{tabular}

